\title{
ІМПЛЕМЕНТАЦІЯ ҐЕНДЕРНО ОРІЄНТОВАНОГО БЮДЖЕТУВАННЯ У ФІСКАЛЬНУ ПОЛІТИКУ ДЕРЖАВИ: ПРОПОЗИЦії ДЛЯ УКРАЇНИ
}

\section{THE IMPLEMENTATION OF GENDER-ORIENTED BUDGETING IN THE FISCAL POLICY OF STATE: RECOMMENDATIONS FOR UKRAINE}

\author{
Карпич Анна Юріївна \\ асистентка, аспірантка, \\ Київський національний університет імені Тараса Шевченка \\ ORCID: https://orcid.org/0000-0001-5345-7299 \\ Чернявка Владислав Андрійович \\ бакалаврант, \\ Київський національний університет імені Тараса Шевченка \\ ORCID: https://orcid.org/0000-0003-1236-1535
}

Karpych Anna, Cherniavka Vladyslav

Taras Shevchenko National University of Kyiv

\begin{abstract}
У статті обґрунтовано імплементацію ґендерно-орієнтованого бюджетування у фріскальну політику України та запропоновано потенційні напрямки його подальшого впровадження задля досягнення ґендерної рівності та наближення до соціальної справедливості у вітчизняному суспільстві. Авторами було узагальнено значення фріскальної політики для соціально-економічного розвитку держави та нинішнього стану економіки України. 3'ясовано, що фріскальна політика в Україні на сьогодні потребує коригувань та перегляду задля подолання наявних кризових явищ у економіці. Встановлено та охарактеризовано місце ґендерно-орієнтованого бюджетування у фріскальній політиці держави. Визначено, що ґендерно-орієнтоване бюджетування є більш ефрективним за умови формування дохідної частини бюджетів з урахуванням ґендерних аспектів. Надано пропозиції щодо розширення імплементації ґендерно-орієнтованого бюджетування в Україні в напрямку впровадження ґендерно-орієнтованого підходу до акумуляції бюджетних доходів.
\end{abstract}

Ключові слова: ґендерно орієнтоване бюджетування, фріскальна політика, публічний фрінансовий менеджмент, ґендерна рівність, Україна.

В статье обоснована имплементация гендерно-ориентированного бюджетирования в фрискальную политику Украины и предложены потенциальные направления его дальнейшего внедрения для достижения гендерного равенства и приближения к социальной справедливости в отечественном обществе. Авторы обобщили значение фрискальной политики для социально-экономического развития государства и нынешнего состояния экономики Украины. Выяснено, что фискальная политика в Украине сегодня нуждается в корректировках и пересмотре для преодоления существующих кризисных явлений в экономике. Установлено и охарактеризовано место гендерно-ориентированного бюджетирования в фрискальной политике государства. Определено, что гендерно-ориентированное бюджетирование становится более эффеектвным при условии фрормирования доходной части бюджетов с учетом гендерных аспектов. Предложено расширить имплементацию гендерно-ориентированного бюджетирования в Украине в направлении внедрения гендерно-ориентированного подхода к аккумуляции бюджетных доходов.

Ключевые слова: гендерно-ориентированное бюджетирование, фрискальная политика, публичный фринансовый менеджмент, гендерное равенство, Украина.

The purpose of this article is to substantiate the further expanded implementation of gender-oriented budgeting in the fiscal policy of Ukraine in order to achieve gender equality within the society. The implementation of gender-oriented budgeting in Ukraine, which was initiated by international organizations and found support at the local and then at the state level, aims to reduce gender gaps in Ukraine and provide conditions for fairer and more transparent budget management. The topicality of this article is conditioned by the growing popularity of the prac- 
tices of gender-oriented budgeting and the current socio-economic crisis in the country caused by the COVID-19 pandemic, which invokes the revision of the fiscal policy in Ukraine in order to improve the national economy and promote gender equality. The article is based on a review of existing Ukrainian and Western academic literature and on the analysis of the reports published by the International Monetary Fund and Razumkov Centre. The results of the research demonstrate the importance of fiscal policy for the socio-economic development of the state and the current situation with Ukraine's economy. The place of gender-oriented budgeting in the fiscal policy of the state is established and characterized. It is determined that gender-oriented budgeting is more effective if the revenue side of budgets is formed taking into account gender aspects. It was found that, today, the fiscal policy in Ukraine needs to be adjusted with the extended use of gender-oriented budgeting if gender gaps are to be closed. The authors give recommendations for expanding the use of gender-oriented budgeting in Ukraine in the direction of implementing a gender-oriented approach to the accumulation of budget revenues. The study has its limitations since the authors did not collect primary data and only secondary sources were analysed. The findings are likely to be useful for those who work with gender-oriented budgeting and the design of fiscal policy. The article may also be of interest for researchers, public servants, government representatives and practitioners who deal with budgets, the budget process, public financial management and gender equality issues.

Keywords: gender-oriented budgeting, fiscal policy, public financial management, gender equality, Ukraine.

Постановка проблеми. Сьогодні наша держава перебуває на важливому етапі свого соціально-економічного та політичного розвитку. Так, зокрема, в Україні прослідковуються трансфрормаційні процеси щодо становлення громадянського суспільства, утвердження цінностей демократичних прав і свобод, що, в свою чергу, вимагає також значної політичної волі.

Обравши рух у напрямку європейської інтеграції, Україна, поміж іншого, взяла на себе зобов'язання щодо забезпечення реалізації тих цінностей, які притаманні західним партнерам. I хоча в нашій країні світогляд мало чим відрізняється від європейського і також полягає в повазі до людини, її прав і гідності, все ж варто відмітити, що в українському соціумі й досі мають місце масштабні прояви соціальної та ґендерної нерівності.

Імплементація ґендерно орієнтованого бюджетування (далі - ҐОБ) в Україні, яка була фрактично ініційована саме міжнародними організаціями та знайшла свою підтримку на місцевому, а потім і на державному рівні, покликана скоротити ґендерні розриви в нашій державі та наблизитися до більш справедливого управління бюджетами. I тут варто усвідомити, що економічна система нашої країни, на даному кризовому етапі свого розвитку, не має можливості фрункціонувати ефективно без державного регулювання та втручання держави в економічні процеси, де саме інструменти фріскальної політики відіграють одну з найголовніших ролей. Через це зважений підхід уряду до фріскальної політики важливий насамперед як в розрізі формування державного бюджету та маневрування його видатковою частиною, так і 3 погляду реалізації дотичних до неї соціальної та гендерної політик, що є актуальним для України, особливо в нинішній ситуації.
Аналіз останніх досліджень і публікацій. Проблематика ҐОБ активно вивчається вже понад чотири десятиліття західними науковцями, серед яких можна виокремити А. О'Геґан, Д. Ельсон, Е. Клатцер, Л. Чакраборті, Н. Шагатай та ін. В Україні ж над цією тематикою почали працювати відносно нещодавно, де за останні декілька років їй вже присвятили свої праці такі вітчизняні вчені: А. Ватульов, О. Голинська, І. Грицай, Т. Коляда, І. Лопушинський, Т. Фесенко та ін.

У свою чергу, питання ролі та реалізації фріскальної політики в державі в значному науковому доробку розглядається протягом декількох століть економістами різних наукових шкіл. Так, основоположними є праці таких закордонних вчених як С. Брю, Дж. Б'юкенен, Дж. М. Кейнс, К. Макконнелл, П. Самуельсон, Дж. Стігліц та ін. Що стосується сучасних українських науковців, які займалися цією проблематикою, то слід зазначити В. Базилевича, Л. Баластрик, О. Василика, А. Крисоватого, І. Лютого, С. Юрія та ін.

Поєднання питань застосування ҐОБ і фріскальної політики держави є досить популярним у західній науковій думці, де його зокрема вивчали В. Алонсо-Альбаран, В. Боїчіч-Джеліловіч, А. А. Гожич, Т. Куррістіне, Дж. Стотскі та ін. Однак на теренах України ҐОБ розглядають переважно лише в розрізі його значимості для бюджетних видатків, де при цьому оминається роль ҐОБ у формуванні доходів бюджетів.

Виділення невирішених раніше частин загальної проблеми. На сьогодні в Україні ҐОБ, як вже було зазначено вище, досліджують, у цілому, з позиції його потенціалу саме для переструктуризації бюджетів у їх видатковій частині, нехтуючи при цьому важливістю ҐОБ для переформовування дохо- 
дів бюджетів з метою просування ґендерної рівності. Однак за такого підходу можливості ҐОБ у фріскальній політиці $€$ обмеженими, адже податкові інструменти є ключовими при боротьбі 3 ґендерними розривами. Разом із тим слід зауважити, що відображення лише такого однобокого спрямування ҐОБ може бути поясненим його втіленням в Україні на практиці, адже вітчизняні інструменти його імплементації зосереджені саме на видатках, а не на включенні ґендерних аспектів у формування дохідної частини бюджетів.

Формулювання цілей статті (постановка завдання). Мета статті полягає в обґрунтуванні подальшої розширеної імплементації ҐОБ у фріскальну політику України для досягнення ґендерної рівності у вітчизняному суспільстві.

Поставлена мета обумовила вирішення таких завдань дослідження:

- узагальнити значущість ролі фріскальної політики для соціально-економічного розвитку держави та поточної економічної ситуації в Україні;

- охарактеризувати місце ҐОБ у фріскальній політиці держави;

- запропонувати потенційні напрямки подальшої імплементації ҐОБ у фріскальну політику України.

Виклад основного матеріалу дослідження. ҐОБ, за рахунок системної інтеграції ґендерної складової та використання відповідних бюджетних інструментів, має на меті досягнення ґендерної рівності, внаслідок чого відбувається також і наближення до соціальної справедливості в суспільстві [1]. Водночас слід підкреслити, що на ґендерну рівність як позитивно, так і негативно впливають абсолютно всі політики, що проводяться державою, адже в їх межах реалізуються відповідні стратегії та виконуються програми, які або зменшують, або збільшують ґендерні розриви.

Розглядаючи фріскальну політику, яка найближче та безпосередньо пов'язана з ҐОБ, можна звернутися до загальновизнаної світовою науковою спільнотою позиції К. Макконнелла та С. Брю [7], згідно якої фріскальна політика передбачає зміни пропорцій у державних видатках і надходженнях від сплати податків, у результаті чого мають бути досягнуті (1) повна зайнятість населення, (2) виробництво неінфрляційного ВВП.

Очевидно, що фріскальна політика виконує ряд надважливих для успішного фрункціонування фрінансової системи функцій. Застосовуючи інструменти фріскальної політики можна, зокрема, знижувати темпи інфрляційних коли- вань, здійснювати антициклічне регулювання економіки, підвищувати обсяги внутрішнього виробництва, а також сприяти проведенню соціальної та гендерної політик держави.

Варто зазначити, що фріскальна політика повинна бути економічно обґрунтованою та мати чітко встановлену правову основу, адже, в протилежному випадку, розвиток фрінансової системи держави зазнаватиме розладів, де матимуть місце негативні наслідки. I в залежності від циклу, в якому перебуває економічна система, уряд має приймати відповідні рішення щодо вибору стимулюючої або стримуючої фріскальної політики (фріскальної експансії чи рестрикції, відповідно).

Необхідно пам'ятати, що до основних фрункцій саме фріскальної політики відносяться перерозподіл національного доходу та акумуляція коштів для подальшого фрінансування соціальних програм. Реалізовуючи фріскальну політику треба вирішувати завдання для сприяння соціально-економічного розвитку держави, де через ії механізми повинні долатися суперечності, котрі виникають між економічною ефективністю та соціальною справедливістю.

Аналізуючи ситуацію з кризою, спричиненою пандемією COVID-19, слід підкреслити значимість фріскальних інститутів, які фрактично постали перед дилемою щодо вибору стратегії задля скорочення бюджетних дисбалансів, де більшість країн обрали шлях зменшення бюджетних доходів разом із утриманням чи розширенням видатків [3].

При цьому варто зауважити, що на теренах України на сьогодні спостерігається скорочення соціальних прав населення, що відображається через зменшення обсягів соціальних виплат від держави, зростання рівня податкового навантаження на населення, а також фріскалізацією суб'єктів підприємницької діяльності [3]. Саме тому в Україні фріскальна політика може бути охарактеризована як така, що потребує більшої розважливості та послідовності з боку уряду, що зумовлюється та підтверджується наявністю кризових явищ у вітчизняній економіці.

Слід також наголосити на необхідності утвердження в нашій державі нової моделі соціально-економічного розвитку, де посилену роль у формуванні та використанні бюджетних коштів будуть відігравати фріскальні механізми та фрінансові інструменти [2]. Розширення застосування практики ҐОБ у поточній ситуації з вітчизняною економікою набуває неабиякої актуальності, адже за його 
імплементації можна забезпечити більш раціональні формування та розподіл фрінансових ресурсів. Інакше висловлюючись, за рахунок вивчення інтересів різних груп жінок і чоловіків ҐОБ дозволяє «підлаштовувати» бюджети під їх бенесріціаріїв, які мають неоднакові можливості та потреби.

Як стверджує відома вчена та експерт із питань ҐОБ Дж. Стотскі [8], економічні результати, зростання та рівноправ'я в державі залежать від її фріскальної політики, що, в свою чергу, обґрунтовує потребу у використанні інструментів ҐОБ (рис. 1).

Про критичну роль врахування ґендерних аспектів при акумулюванні дохідної частини бюджетів йдеться в дослідженні вчених В. Боїчіч-Джеліловіч та А. А. Гожич [5], де на прикладі країн Західних Балкан ними було з'ясовано, що за рахунок, поміж іншого, запровадження податку на додану вартість на споживання домогосподарств (VAT on household consumption) відбулося погіршення економічного стану жінок у цьому регіоні. Тому дослідниці піддали критиці імплементацію ҐОБ у Західних Балканах, яка зосереджується на переструктуруванні бюджетних видатків.

У нещодавньому дослідженні країн Великої двадцятки (G-20) В. Алонсо-Альбаран та ін. [6] порушують проблему забезпечення досягнення ґендерної рівності зокрема під час пандемії COVID-19, за якої ґендерні розриви лише посилилися. Так, у цій праці наголошується, що за допомогою практики ҐОБ з'являється розуміння впливу політики держави щодо бюджетних видатків і доходів на становище жінок і чоловіків, дівчат і хлопців. Також наводяться приклади Італії та Іспанії, де приділяється особлива увага ґендерно-орієнтованому орормуванню дохідної частини бюджетів [6].

Можна констатувати, що зосередження лише на видатковій частині бюджетів $€$ хибною стратегією для подолання ґендерної нерівності. Тому для України варто розширити межі застосування ҐОБ та здійснити його орієнтацію й на те, яким чином у нас в державі відбувається акумуляція бюджетних доходів.

Водночас для подальшої імплементації ҐОБ у фріскальну політику України необхідна, перш за все, політична воля з боку вітчизняного суспільства та представників влади. Тут варто зазначити, що питання політичної волі нерозривно пов'язане з концепцією згоди, що в нашій державі, як свідчить історична ретроспектива, досягається в разі небезпеки чи перебування на межі виживання [4], на жаль.

Тому, зважаючи на поточну ситуацію в Україні, доцільно запропонувати якомога швидше сконцентрувати спільні зусилля для запобігання подальшої ескалації наявних кризових явищ у вітчизняній економіці, де одним із таких кроків буде розширене впровадження ҐОБ у фріскальну політику.

Для цього в Україні $€$ низка передумов, серед яких можна назвати вже розпочату на

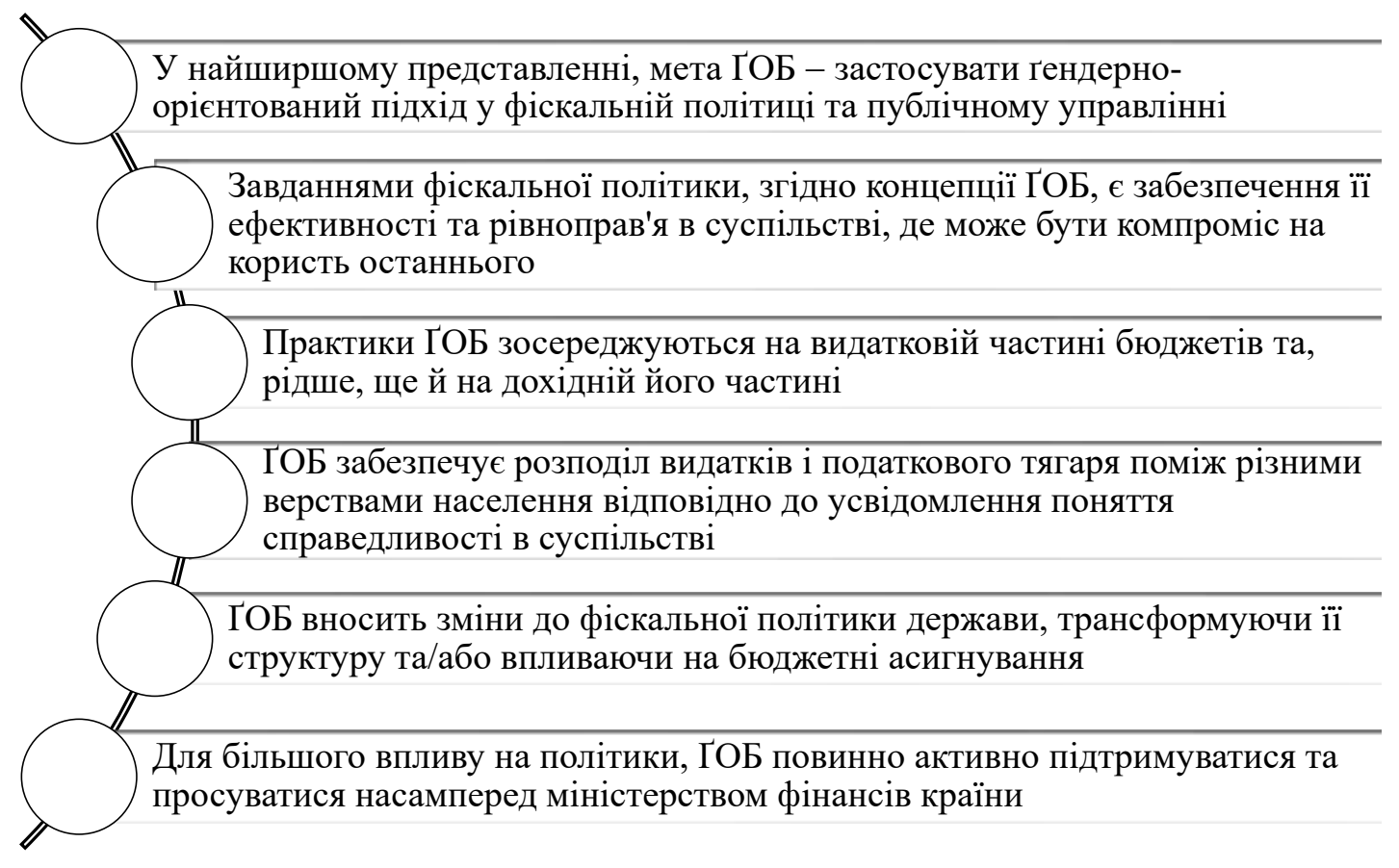

Рис. 1. Місце ґОБ у фіскальній політиці держави

Джерело: побудовано автором на основі [8] 
теренах нашої держави імплементацію ҐОБ, обов'язкове застосування програмно-цільового методу в бюджетному процесі та середньострокове бюджетне планування. При цьому, використання податкових стимулів і податкових канікул для окремих найбільш вразливих груп також можуть стати вагомим елементом проведення ҐОБ.

Висновки. Отже, можна підбити підсумки, що інтеграція ҐОБ у фріскальну політику держави покликана сприяти досягненню ґендерної рівності в суспільстві. Вагомий вплив на скорочення ґендерних розривів має зосередження ҐОБ саме на формуванні дохідної частини бюджетів, що в світовій практиці реалізується рідше, ніж фоокусування ҐОБ на бюджетних видатках, а в нашій державі взагалі не відбувається. Подальша імплементація ҐОБ в Україні має бути розширена за рахунок включення ґендерних аспектів до процесу акумуляції доходів бюджетів, із можливим подальшим застосуванням відповідних податкових інструментів для забезпечення ґендерної рівності.

\section{СПИСОК ВИКОРИСТАНИХ ДЖЕРЕЛ:}

1. Карпич А.Ю. Теоретичні підходи до визначення категорії «ґендерно орієнтоване бюджетування» в українській науковій думці. Економіка та суспільство. 2021. № 24. DOI: https://doi.org/10.32782/2524-0072/2 021-24-41

2. Лютий І., Осецька Д. Соціальні пріоритети фіскальної політики в посткризовий період. Вісник Київського національного університету імені Тараса Шевченка. Економіка. 2014. Вип. 1(154). С. 28-33.

3. Пищуліна О., Юрочко Т., Юрчишин В. Соціально-економічні наслідки коронакризи. Київ, 2021. Разумков Центр : [сайт]. URL: https://razumkov.org.ua/uploads/article/2021_Socialno-Ekonomichni_naslidky_koronakryzy.pdf

4. Смірнова В. О. Політична воля як чинник державотворчої діяльності: об'єктивні та суб'єктивні детермінанти : монограсрія. Київ : Логос, 2019. 384 с.

5. Bojičić-Dželilović V., Hozić A. A. Taxing for inequalities: gender budgeting in the Western Balkans. Review of International Political Economy : RIPE. 2020. № 27(6). P. 1280-1304. DOI: https://doi.org/10.1080/09692290.2019.1702572

6. Gender Budgeting in G20 Countries : IMF Working Paper 21/269 / V. Alonso-Albarran. International Monetary Fund : [сайт]. URL: https://www.imf.org/-/media/Files/Publications/WP/2021/English/wpiea2021269-print-pdf.ashx

7. McConnell C. R., Brue S. L., Flynn, S. M. Economics: Principles, Problems, and Policies (18th ed.). New York : McGraw-Hill//rwin, 2008. 880 p.

8. Stotsky J. G. Gender budgeting: fiscal context and current outcomes: IMF Working Paper 16/149. International Monetary Fund : [сайт]. URL: https://www.imf.org/external/pubs/ft/wp/2016/wp16149.pdf

\section{REFERENCES:}

1. Karpych, A. (2021) Teoretychni pidkhody do vyznachennia katehorii "genderno oriientovane biudzhetuvannia" v ukrainskii naukovii dumtsi [Theoretical approaches to the definition of the "gender oriented budgeting" in Ukrainian economic thought]. Ekonomika ta suspil'stvo, 24. DOI: https://doi.org/10.32782/2524-0072/2021-24-41 (in Ukrainian)

2. Lyutyy, I. \& Osetska, D. (2014) Sotsialni priorytety fiskalnoi polityky v postkryzovyi period [Social priorities of fiscal policy in post-crisis period]. Bulletin of Taras Shevchenko National University of Kyiv. Economics, 1(154), 28-33. (in Ukrainian)

3. Pyshchulina, O., Yurochko, T., Yurchyshyn, V. Sotsialno-ekonomichni naslidky koronakryzy [Socio-economic consequences of the coronavirus crisis]. Retrieved from: https://razumkov.org.ua/uploads/article/2021_SocialnoEkonomichni_naslidky_koronakryzy.pdf (in Ukrainian)

4. Smirnova, V. O. (2019) Politychna volia yak chynnyk derzhavotvorchoi diialnosti: obiektyvni ta subiektyvni determinanty [Political will as a factor of state-building activity: objective and subjective determinants]. Kyiv: Logos. (in Ukrainian)

5. Bojičić-Dželilović, V., \& Hozić, A. A. (2020) Taxing for inequalities: gender budgeting in the Western Balkans. Review of International Political Economy: RIPE, 27(6), 1280-1304. DOI: https://doi.org/10.1080/09692290.2019.1702572

6. Alonso-Albarran, V., Curristine, T., Preston, G., Soler, A., Tchelishvili, N., \& Weerathunga, S. (2021) Gender Budgeting in G20 Countries. (Vol. 21/269). International Monetary Fund. Retrieved from: https://www.imf.org/-I media/Files/Publications/WP/2021/English/wpiea2021269-print-pdf.ashx

7. McConnell, C. R., Brue, S. L., Flynn, S. M. (2008) Economics: Principles, Problems, and Policies (18th ed.). New York: McGraw-Hill//rwin.

8. Stotsky, J. G. (2016) Gender budgeting: fiscal context and current outcomes (Vol. 16/149). International Monetary Fund. Retrieved from: https://www.imf.org/external/pubs/tt/wp/2016/wp16149.pdf 